\title{
INFLUENCE OF GAMMA RADIATION OF INDOOR RADON DECAY PRODUCTS ON ABSORBED DOSE RATE
}

\author{
Laima Pilkytè ${ }^{1,2}$, Donatas Butkus ${ }^{1}$ \\ ${ }^{1}$ Dept of Environmental Protection, Vilnius Gediminas Technical University, \\ Sauletekio al.11,LT-10223 Vilnius-40, Lithuania.E-mail: aak@ap.vtu.lt \\ ${ }^{2}$ Radiation Protection Centre, Kalvariju g. 153, LT-08221 Vilnius-42, Lithuania. \\ E-mail: l.pilkyte@rsc.lt
}

Received 27 Jan 2005; accepted 17 Mar 2005

\begin{abstract}
A survey of absorbed dose rate and indoor radon concentration in multistorey houses was carried out. The main source of radon in such houses is construction materials. There is a relationship between absorbed dose rate and indoor radon concentration. This relationship is rather complicated and different for different premises. It depends on the geometry of premises and other characteristics which influence the distribution of indoor radon daughters. Increment of absorbed dose rate per unit of increment of indoor radon concentration depends on the concentration of indoor radon, floor where premises are situated, geometry of premises. The results of this study might help to assess the dose due to indoor radon which originates from construction materials.
\end{abstract}

Keywords: natural radionuclides, external exposure to ionizing radiation, indoor radon, absorbed dose rate, construction materials.

\section{Introduction}

Natural sources of ionizing radiation are the most important pathway of radiation exposure to the general population. They consist of cosmic radiation, ionizing radiation from naturally occurring radionuclides in soil $\left({ }^{226} \mathrm{Ra},{ }^{232} \mathrm{Th}\right.$ and their decay products, $\left.{ }^{40} \mathrm{~K}\right)$, radiation of radon (decay product of ${ }^{226} \mathrm{Ra}$ ) and its decay products [1]. They cause the exposure outdoors [2, 3] and indoors $[1,4]$. Exposure from radionuclides in construction materials is a significant source indoors.

Doses from natural sources are being analysed and assessed. Measures to optimize radiation protection of people that are affected by these sources, $i$ e to achieve the doses as low as possible, are identified.

Problems are encounterred when these doses are analysed and assessed. In some cases it is enough to perform measurements of concentrations of the radionuclide which is the source of exposure (e g indoor radon). In some other cases such measurements might be insufficient. $\mathrm{E} g$ it is complicated to estimate doses due to external exposure which is caused by indoor radon. The reason for this is the fact that external exposure (dose rate) indoors is caused by a few sources: cosmic radiation, indoor radon, radiation of radionuclides in construction materials $[1,5,6]$. If measurements of dose rate indoors are performed with a dose-rate meter, there is no possibility to identify impact of each of the above mentioned sources.

Indoor radon is usually the main source of exposure [1]. The main source of radon in Lithuania is the soil [7]. However, in some cases (e $\mathrm{g}$ in premises which are far above the ground, $i$ e on higher floors) the main source of radon might be construction materials. Though very often construction materials are considered from the point of view of direct exposure it is important to know that radon exhaled after decay of radium in construction materials [8,9] might cause significant doses (e g the case of alumn shale rich "blue" concrete in Sweden [10]). More and more frequently by-products (e g phosphogypsum) are used for the production of construction materials, and the latter acquire physical properties which facilitate exhalation of radon from these materials. Impact of construction materials as a source of exposure might increase due to these reasons, particularly in multistorey buildings. For this reason it is important to elaborate techniques which might help to assess quickly how much radon is released from construction materials. 
In order to identify the significance of construction materials as a source of radon it is important to determine the peculiarities of concentration variations of indoor radon in premises where construction materials are an important source of radon, relationship of these activities with other parameters, e $\mathrm{g}$ absorbed dose rate indoors.

The results received during the investigation of relationship between absorbed dose rate and concentration of indoor radon in multistorey houses are presented in this paper.

\section{Object of the study}

Dependence of absorbed dose rate indoors on indoor radon concentration in multistorey houses is analysed in this study. For comparison, the results of analogous measurements in detached houses are given.

This study has an aim to determine how absorbed dose rate is related with indoor radon concentration in cases when the main source of indoor radon is construction materials. This is the case in multistorey house premises which are far above the ground, and radon cannot easily enter them.

Such an assessment is important for determination of possible impact of radon released from construction materials on doses.

\section{Methods}

Two types of measurements were performed. The first type was measuring of average indoor radon concentrations, the second one - measuring of temporal variations of indoor radon concentration. The first type allows examination of many premises, the second one detailed long-term measurements in the same room.

The first method uses ion chambers with E-PERM ${ }^{\mathrm{TM}}$ electrets (Electret Passive Environmental Radon Monitor) for determining average radon concentrations in a room. The method is based on discharge of preliminary charged electrets by radon daughters and the fact that this discharge (potential drop of the electret surface) depends on the concentration of radon and duration of measurement. Radon concentrations are measured in $\mathrm{Bq} \cdot \mathrm{m}^{-3}$. In order to determine average radon concentrations, measurements using electret radon detectors were carried for 3-4 weeks in the same room.

The concentrations of indoor radon are calculated using the following equation:

$$
C=\frac{I-F}{k T}-K_{f},
$$

where $I$ - surface potential at the beginning, $F$ - surface potential at the end, $T$ - measurement time in days, $k-$ coefficient of calibration, $K_{f}$ - corrective factor for impact of gamma ray on electret potential difference.

The coefficient of calibration is calculated by:

$$
k=1,6978+0,0005742(I+F) / 2 .
$$

Impact of gamma radiation is taken into account by:

$$
K_{f}=0,322 H
$$

where $H$ - absorbed dose rate, $n \mathrm{~Gy} \cdot \mathrm{h}^{-1}$.

The uncertainty of measurements is calculated by:

$$
E O=\sqrt{\left(\frac{I-F}{k T}\right)^{2}\left(0,0025+\frac{2}{(I-F)^{2}}\right)+\left(0,10 K_{f}\right)^{2}} .
$$

Location for measurement in a room was selected at a height of 1 to 1,5 meter farther away from ceramic tiles (they usually contain high concentrations of natural radionuclides), windows, doors, heating and ventilation systems. The absorbed dose rate in air in the same place was recorded at the beginning and at the end of each measurement of indoor radon concentration. The mean value of absorbed dose rate was defined from 3 to 5 separate measurements. Absorbed dose rate was measured in $n \mathrm{~Gy} \cdot \mathrm{h}^{-1}$.

When performing these measurements, the type of construction materials, number of floors in a building, floor of measurements, age of a building were recorded. The type of interior construction materials was not registered.

For calculating the results, the software RADON.EXE was used. It was also used for creating a database [11].

For quality assurance, intercomparisons are essential. At the time of this survey the used equipment electret radon detectors were sent for intercomparison of passive radon detectors in 2002, organized by NRPB (National Radiological Protection Board of the United Kingdom). The achieved results were ranked in the best category [12].

Another measurement type was continuous measurements of variations of indoor radon concentration using a radon monitor AlphaGUARD PQ2000 with a 0,56 liter active volume ionizing chamber. Ionization current in the chamber depends on the intensity of ionizing radiation which depends on radon concentration in the chamber. Radon enters the chamber through a glass-fiber filter that prevents from entering radon decay products present in the room air. One radon concentration value is received within one hour.

Calibration of an instrument for continuous radon measuring was performed in a specially designed radon room in the Swedish Radiation Protection Authority (SSI) in 2002. Reference measurements were carried out with the instrument for a continuous registration of radon based on alpha spectrometry. A working standard with a calibration traceable to National Institute of Standards and Technology (NIST) (USA) was used.

Dose rate measurements were performed in the same 
place in the room. Temporal dose rate variations were measured with the monitor GammaTracer with GeigerMuller detector every two hours. The results were analysed with the software Aexpert and Gexpert.

Statistical analysis of the results was made using the standard MS Excel software.

Influence of cosmic radiation on absorbed dose rate indoors was evaluated taking into account the floor where the measurements were performed. According to [13], the first - third floors are reached by 0,66 of initial cosmic radiation (present outdoors), the fourth - twelfth floors - by 0,72 . Dose rate due to cosmic radiation in Lithuania is $33 n \mathrm{~Gy} \cdot \mathrm{h}^{-1}$ outdoors.

\section{Results and their analysis}

Measurements were carried out from October 2001 until January 2004 during heating seasons in two most often used rooms of flats in multistorey houses (609 rooms in 304 flats). The houses had from 3 to 12 floors. Most of the flats investigated (65\%) were in five-storey houses. According to the information of Department of Statistics, five-storey houses make up the majority among multistorey houses in Lithuania.

All the investigated houses had basements, however, the results of measurements performed in basements are not used in the analysis because these places usually are not used for living. Only one flat was found in a basement in Vilnius where an average radon concentration was $167 \mathrm{~Bq} \cdot \mathrm{m}^{-3}$, average absorbed dose rate $-175 n \mathrm{~Gy} \cdot \mathrm{h}^{-1}$. The result of this measurement was not used either.

It was rather complicated to perform measurements on each floor of the same stairwell of a house. However, in order to decrease the number of parameters influencing indoor radon concentration (e g the soil impact which is different in different locations), a part of measurements was carried out in flats on each floor of the same stairwell of a building. 45 houses were investigated in this way.

A survey was carried out in flats of houses built according to the information provided by inhabitants from 1959 to 2001, on average in 1975.

Measurements were performed mainly in the largest Lithuanian cities. Information on the number of investigated flats in different cities, average radon concentration and average absorbed dose rate is given in Table 1.

36 flats were investigated in other towns and are not included in Table 1.

Distribution of radon concentration and absorbed dose rate is in Figs 1, 2 and aplies to rooms.

It is evident that distribution of radon concentration and absorbed dose rate is log-normal. Absorbed dose rate can vary several times in different rooms and buildings, indoor radon concentration vary around ten times.

The results received on different floors are presented in Table 2. Such a division of the results is very important because usually indoor radon concentrations depend
Table 1. Number of measurements in multistorey houses in different cities, average radon concentration and average absorbed dose rate

\begin{tabular}{|l|c|c|c|}
\hline \multicolumn{1}{|c|}{ City } & $\begin{array}{c}\text { Number of } \\
\text { measurements }\end{array}$ & $\begin{array}{c}\text { Average indoor } \\
\text { radon concen- } \\
\text { tration*, } \mathrm{Bq}^{-3}{ }^{-3}\end{array}$ & $\begin{array}{c}\text { Average } \\
\text { absorbed dose } \\
\text { rate* }, n \mathrm{~Gy}^{-1}\end{array}$ \\
\hline Klaipėda & 129 & $8 \pm 2$ & $143 \pm 2$ \\
\hline Panevěžys & 125 & $16 \pm 2$ & $118 \pm 3$ \\
\hline Šauliai & 109 & $19 \pm 2$ & $105 \pm 3$ \\
\hline Vilnius & 210 & $15 \pm 2$ & $123 \pm 2$ \\
\hline
\end{tabular}

* - averages here and below given with $95 \%$ confidence

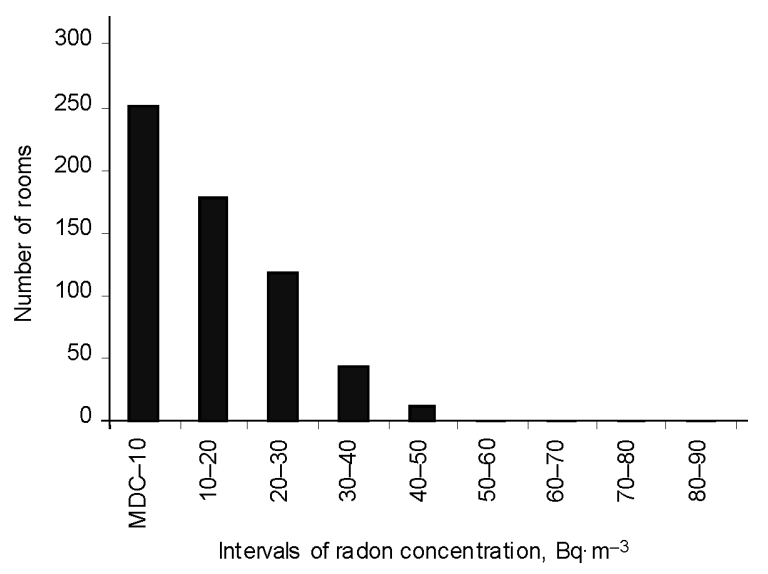

Fig 1. Distribution of indoor radon concentration. MDC minimal detectable concentration $-1 \mathrm{~Bq} \cdot \mathrm{m}^{-3}$

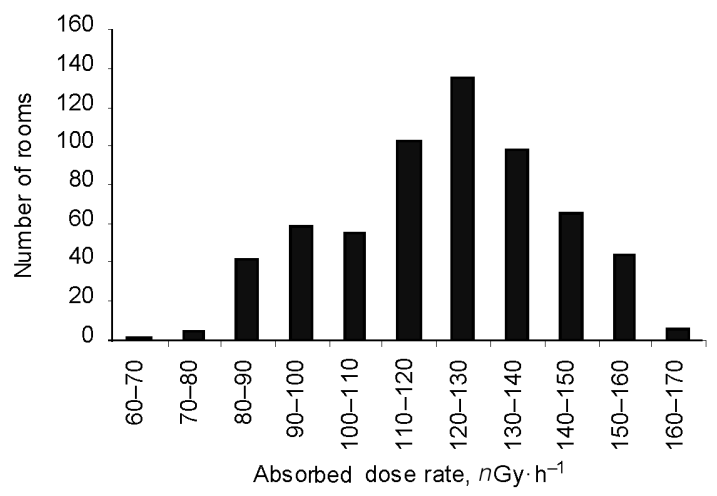

Fig 2. Distribution of absorbed dose rate

Table 2. Results for different floors

\begin{tabular}{|c|c|c|c|}
\hline Floor & $\begin{array}{c}\text { Number of } \\
\text { measurements }\end{array}$ & $\begin{array}{c}\text { Average indoor } \\
\text { radon concent- } \\
\text { ration*, } \mathrm{Bq} \cdot \mathrm{m}^{-3}\end{array}$ & $\begin{array}{c}\text { Average absorbed } \\
\text { dose rate* } \\
n \mathrm{~Gy}^{-1}\end{array}$ \\
\hline 1 & 111 & $19,4 \pm 2,7$ & $103 \pm 4$ \\
\hline 2 & 103 & $12,5 \pm 2,5$ & $101 \pm 4$ \\
\hline 3 & 111 & $14,2 \pm 2,3$ & $101 \pm 4$ \\
\hline 4 & 99 & $13,3 \pm 2,3$ & $97 \pm 4$ \\
\hline 5 & 115 & $16,8 \pm 2,0$ & $97 \pm 4$ \\
\hline 6 & 14 & $17 \pm 7$ & $95 \pm 14$ \\
\hline 7 & 18 & $14,4 \pm 4,2$ & $96 \pm 11$ \\
\hline 8 & 12 & $16 \pm 9$ & $92 \pm 14$ \\
\hline 9 & 16 & $8,8 \pm 3,6$ & $104 \pm 11$ \\
\hline 10 & 4 & $6,7 \pm 3,2$ & $111 \pm 4$ \\
\hline 11 & 2 & $14 \pm 10$ & $106 \pm 1$ \\
\hline 12 & 4 & $17 \pm 11$ & $112 \pm 10$ \\
\hline
\end{tabular}

* - average with $95 \%$ confidence 
on a floor, i e the distance from the ground. The values of absorbed dose rate are given without dose rate due to cosmic radiation, taking into account the differences of absorption of cosmic radiation on different floors.

As it is seen, no statistically significant differences among absorbed dose rates on different floors and indoor radon concentrations on different floors (higher than the ground floor) were detected. The fact that no differences exist in indoor radon concentrations show that impact of the soil on radon concentrations in premises above the ground floor is small. Different impact of cosmic radiation on different floors is also not easily identified. Besides, it was not the aim of this study.

The largest part of measurements was carried out on the first five floors $(89 \%)$. Houses for investigation were selected randomly, and this fact reflects how flats are distributed according to the floor.

The results of measurements performed in flats on each floor of the same building were analysed using statistical $\mathrm{t}$-test. Statistically significant differences among absorbed dose rates on different floors were not found. Indoor radon concentration on the ground floor statistically significantly differ from those on the first floor $(p<0,05)$.

The analysed multistorey houses were built of concrete (reinforced concrete) $(51 \%)$ and bricks (49\%). Statistically significant difference was found by t-test between absorbed dose rate indoors in houses constructed of bricks and concrete ones $(p<0,01)$. An average absorbed dose rate in houses built of bricks is $(126 \pm 2)$

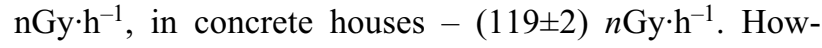
ever, this difference cannot be connected directly with the concentrations of radionuclides in the construction materials given in Table 3 .

The values of activity indexes are also given in Table 3. These parameters are used for overall evaluation of construction materials from the point of view of radiation protection. Activity indexes are calculated using the equation:

$$
I=\frac{a_{R a}}{300}+\frac{a_{T h}}{200}+\frac{a_{K}}{3000},
$$

where $a_{R a}, a_{T h}, a_{K}-$ concentrations of ${ }^{226} \mathrm{Ra},{ }^{232} \mathrm{Th}$ and ${ }^{40} \mathrm{~K}$ in becquerel per kilogram.

Table 3. Typical concentrations of radionuclides and activity indexes of common construction materials

\begin{tabular}{|l|c|c|c|c|}
\hline \multirow{2}{*}{ Material } & \multicolumn{3}{|c|}{ Concentration, $\mathrm{Bq} \cdot \mathrm{kg}^{-1}$} & \multirow{2}{*}{$I$} \\
\cline { 2 - 4 } & ${ }^{226} \mathrm{Ra}$ & ${ }^{232} \mathrm{Th}$ & ${ }^{40} \mathrm{~K}$ & \\
\hline Concrete poles & $43 \pm 9$ & $16 \pm 3$ & $622 \pm 99$ & 0,43 \\
\hline $\begin{array}{l}\text { Reinforced } \\
\text { concrete }\end{array}$ & $29 \pm 6$ & $12 \pm 2$ & $391 \pm 62$ & 0,29 \\
\hline $\begin{array}{l}\text { Concrete } \\
\text { aggregate }\end{array}$ & $33 \pm 6$ & $12 \pm 2$ & $378 \pm 60$ & 0,29 \\
\hline Porous concrete & $31 \pm 7$ & $10 \pm 2$ & $320 \pm 51$ & 0,26 \\
\hline White bricks & $21 \pm 4$ & $9,8 \pm 1,5$ & $432 \pm 57$ & 0,26 \\
\hline
\end{tabular}

Uncertainties are given with coverage factor $k=2$
The fact, that absorbed dose rate is not directly connected with radionuclide concentrations in construction materials, shows that there are other parameters which are important for dose rate indoors. It is discussed below.

Distributions of absorbed dose rate in concrete and brick buildings are presented in Fig 3. Both distributions are of the same type, the differences are in average dose rates.

There is no statistically significant difference between indoor radon concentrations in concrete houses and houses built of bricks $(p=0,4)$.

In order to find out an influence of indoor radon daughters on absorbed dose rate, relationship between absorbed dose rate and indoor radon concentration in the same room was analysed.

It was considered that concentrations of radon daughters were proportional to indoor radon concentration in the same premises.

An appropriate chart received from all the results is given in Fig 4. Two approximations - linear and polynomial ones - are used. The last one was used for a more precise approximation of relationship between ab-

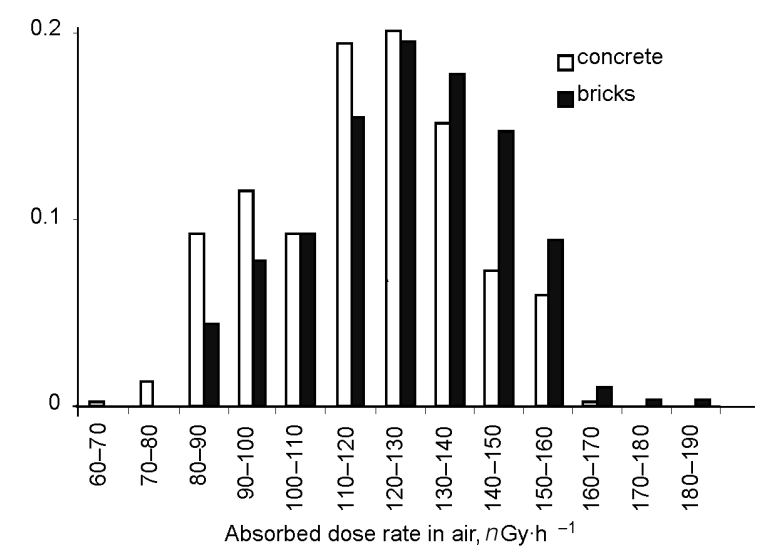

Fig 3. Distribution of absorbed dose rate in rooms of buildings built of different construction materials

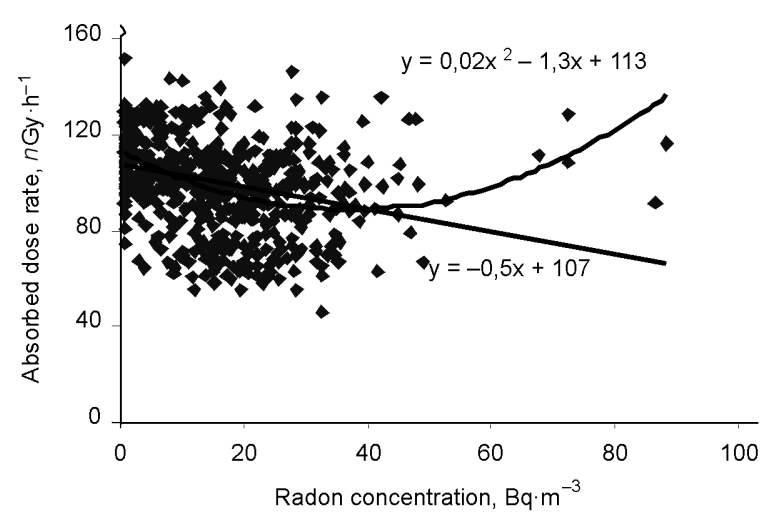

Fig 4. Relationship of absorbed dose rate (without cosmic radiation) and radon concentration on all the floors and investigated houses 
sorbed dose rate and indoor radon concentration in different intervals of radon concentrations.

It is seen from Fig 4 that in case a linear approximation is used, absorbed dose rate decreases with increase of indoor radon concentration. If a polynomial approximation of the $2^{\text {nd }}$ order is used, absorbed dose rate decreases when indoor radon concentration increases in the range approximately below $40 \mathrm{~Bq} \cdot \mathrm{m}^{-3}$, and when this concentration is exceeded, absorbed dose rate increases with increase of indoor radon concentration. Explanation of relationship when dose rate decreases with increase of indoor radon concentration is complicated.

In order to determine if cosmic radiation has no influence on such a type of relationship and taking into account that elimination of impact of cosmic radiation is rather complicated, analogous relationships were determined for different floors (for the first to fifth floors). Similar curves were received during approximation of these relationships. These curves are given in Table 4.

The results in Table 4 show that approximations for different floors are similar. It indicates that cosmic radiation does not have any influence on this relationship. Its intensity due to different absorption on different floors does not have any impact.

It is evident that indoor radon concentration and absorbed dose rate decrease with floors (Figs 5, 6).

In order to eliminate as much as possible of parameters important for indoor radon concentration and absorbed dose rate, measurements were performed simultaneously in the same premises (the above mentioned measurements of the second type). The results of a part of these measurements are presented in Fig 7. Dose rate due to cosmic radiation in this case was not subtracted because it has no impact on the shape of an approximation curve.

It is evident from Fig 7 that dose rate increases with increase of indoor radon concentration, and such a relationship might be easily explained.

Relationships of the same type were received during measurements of the second type in other premises and on other floors. Differences are only in inclination of an approximation line. The differences of inclination might be explained by the fact that absorbed dose rate depends not only on the activity of a radiation source, but also on its geometry. The geometry, on the other

Table 4. Equations of linear and polynomial approximations of relationships between absorbed dose rate (corrected for absorption of cosmic radiation on different floors) and indoor radon concentration on different floors $(x-$ indoor radon concentration)

\begin{tabular}{|c|c|c|}
\hline Floor & $\begin{array}{c}\text { Equation of linear } \\
\text { approximation }\end{array}$ & $\begin{array}{c}\text { Equation of polynomial } \\
\text { approximation }\end{array}$ \\
\hline 1 & $-0,3 x+109$ & $0,02 x^{2}-1,3 x+117$ \\
\hline 2 & $-0,5 x+107$ & $0,01 x^{2}-1,1 x+111$ \\
\hline 3 & $-0,14 x+103$ & $0,05 x^{2}-1,9 x+112$ \\
\hline 4 & $-0,5 x+103$ & $0,03 x^{2}-1,8 x+112$ \\
\hline 5 & $-0,8 x+112$ & $0,03 x^{2}-2,0 x+118$ \\
\hline
\end{tabular}

hand, depends on dimensions of premises under investigation and concentrations of aerosols in the air of premises. Behavior of newly-born indoor radon daughters depend on the last parameter. If concentration of aerosols is comparatively low, the radon daughters deposit on surfaces indoors faster. If concentrations of aerosols are higher, the radon daughters will deposit mainly on

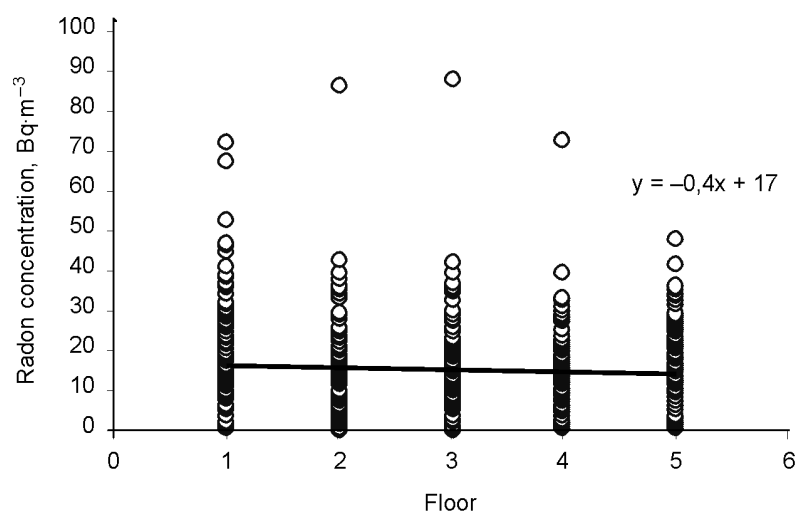

Fig 5. Indoor radon concentration in rooms on different floors and their linear approximation

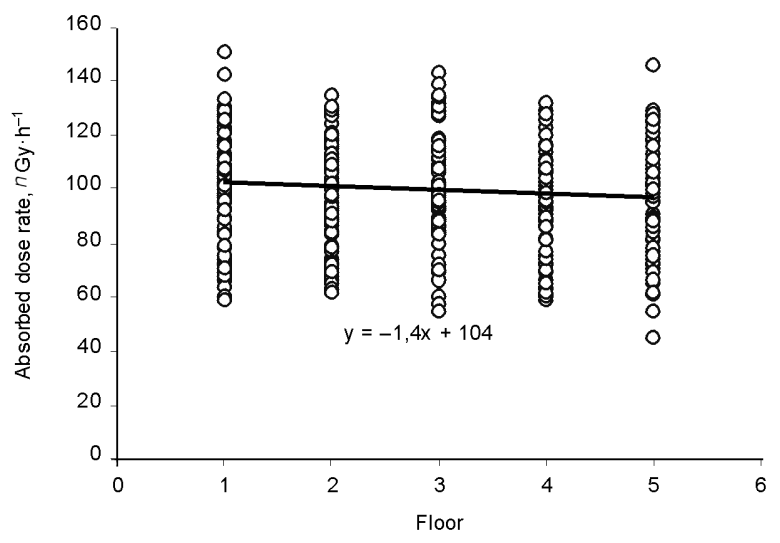

Fig 6. Absorbed dose rate (corrected for cosmic radiation on different floors) in rooms on different floors and its linear approximation

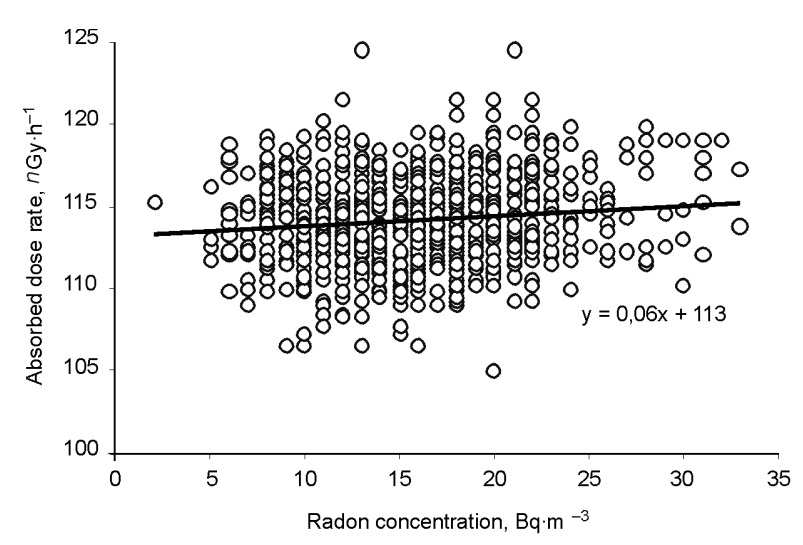

Fig 7. Relationship between absorbed dose rate and indoor radon concentration measured simultaneously in the same flat on the seventh floor of a nine-storey building in January - February 2003, and its linear approximation 
aerosols and remain longer suspended in the air of premises. The geometry of a radiation source is different in both cases, and it will cause different conditions for external exposure and different values of absorbed dose rate. Such considerations are very important in premises of smaller dimensions.

The coefficients of relationship between absorbed dose rate and the activity of a source (dose factors) are given in different manuals and handbooks on radiation protection. It is important to emphasize that these dose factors are determined for point, infinite and semi-infinite sources (for idealized geometry). Application of these coefficients for realistic geometry (rooms of a limited size) might cause uncertainties in dose assessments.

Relationship between absorbed dose rate and indoor radon concentration in detached houses is presented in Fig 8 . These data were received during a national survey of indoor radon concentrations in 400 randomly selected detached houses in 1995-1998 [11]. Techniques of measurements were the same as those employed in this study. The presented values of absorbed dose rate include the part caused by cosmic radiation because nearly all the measurements were performed on the first floor of one-storey houses, and the impact of cosmic radiation was approximately the same in all the investigated houses.

The relationship in this case is easily explained absorbed dose increases with indoor radon concentration.

Similar results were received when analysing the data collected during measurements of indoor radon concentrations and absorbed dose rates performed in 20002004 (Fig 9). These measurements were performed in areas where comparatively high indoor radon concentrations were found during the survey of 1995-1998. The measurements have been performed in 1356 detached houses.

Though impact of the soil on indoor radon concentration in detached houses is much more important, such a relationship between absorbed dose rate and indoor

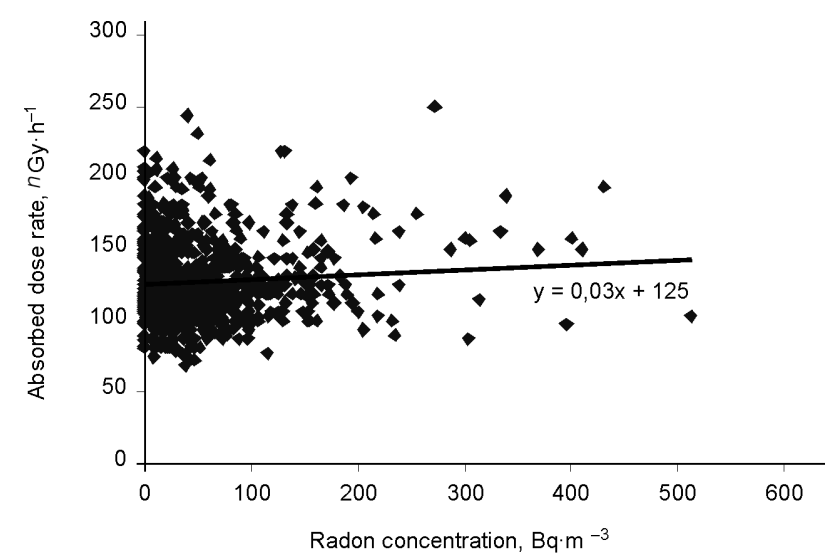

Fig 8. Relationship between absorbed dose rate and indoor radon concentration in detached houses and its linear approximation (survey results of 1995-1998) radon concentration is received because of the fact that the range of indoor radon concentrations in detached houses is much wider than that in multistorey ones.

There are differences in increment of absorbed dose rate per unit of increment in indoor radon concentration. Its values in this study are from 0,006 to $0,06 n \mathrm{~Gy}$. $\mathrm{h}^{-1} \cdot\left(\mathrm{Bq} \cdot \mathrm{m}^{-3}\right)^{-1}$. [14] reported a semi-empirical increment for a single-family house equal to $0,01 n \mathrm{~Gy} \cdot \mathrm{h}^{-1}$. for increment of radon daughter concentrations at an equilibrium of $1 \mathrm{~Bq} \cdot \mathrm{m}^{-3},[13]-(0,15-0,18) n \mathrm{~Gy} \cdot \mathrm{h}^{-1} \cdot\left(\mathrm{Bq} \cdot \mathrm{m}^{-3}\right)^{-1}$. Due to the above mentioned reasons connected with the geometry of a source of exposure (distribution of radon daughters indoors), it is impossible to determine one value for increment of absorbed dose rate per unit of increment in indoor radon concentration.

It is important to keep this fact in mind when measurements of indoor radon concentrations are planned and their techniques are selected. It is particularly relevant for cases when the main source of indoor radon is construction materials. In some cases gamma spectrometric measurements are performed with a gamma spectrometer placed in the middle of a room. After that, taking into account the concentrations of radionuclides in structural elements of a building, efforts for calculating the concentrations of indoor radon daughters are made. Considering uncertainties in the distribution of radon daughters indoors such a way of evaluating the concentrations of indoor radon daughters is imprecise.

It is evident that relationship between absorbed dose rate and indoor radon concentration is a complex one. This relationship might be also negative. Such a negative relationship might be explained by the fact that distribution of radon daughters indoors may change with changes in ventilation of premises. When the data received in different by many aspects premises are analysed, parameters the impact of which on absorbed dose rate hides the impact of indoor radon, might become important.

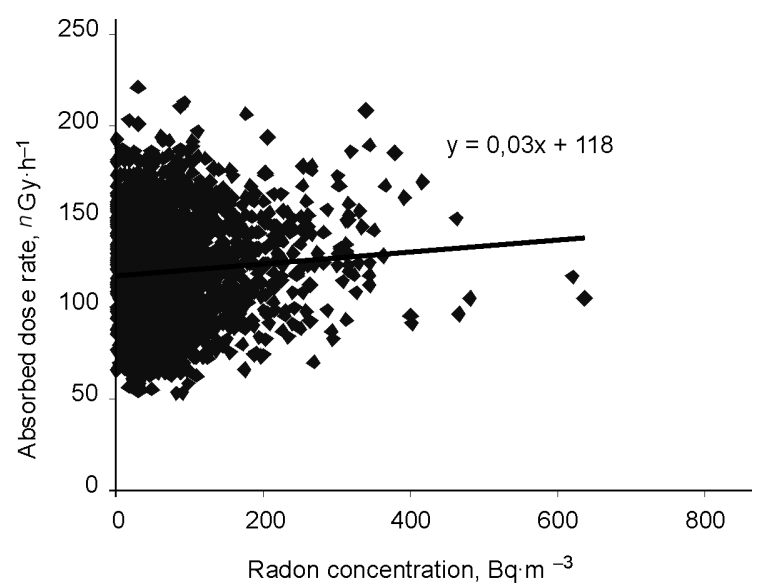

Fig 9. Relationship between absorbed dose rate and indoor radon concentration in detached houses (measurement results of 2000-2004 in areas with higher radon concentrations found in 1995-1998) 
This problem is solved by measurements of the second type in the same premises. Such measurements shall be performed within some time interval which depends on the duration of obtaining a single value thus assuring a sufficient statistics. The duration of measurement in one premise should be approximately one month.

It is important to emphasize the fact that, though in multistorey houses where on higher floors construction materials are important for indoor radon concentrations, relationship between absorbed dose rate and indoor radon concentration is not so simple.

It is stated in [13] that indoor radon concentration depends on absorbed dose rate, i e indoor radon concentration depends on the concentration of radium in construction materials which determines dose rate, $i$ e that relationship between indoor radon concentration and absorbed dose rate is indirect.

The results of this study, received during long-term measurements in the same premises, show that relationship between indoor radon concentration and absorbed dose rate is more complex. Absorbed dose rate was changing though the concentration of natural radionuclides including radium in construction materials was constant. The clearly expressed trend of changes in absorbed dose rate with changes of indoor radon concentration shows that there might also exist a direct relationship between these two parameters.

\section{Conclusions}

1. There is a relationship between absorbed dose rate and indoor radon concentration. This relationship depends on the geometry of premises and other characteristics which influence distribution of radon daughters indoors.

2. No statistically significant differences in absorbed dose rate and indoor radon concentration on different floors (higher than the ground floor) were detected. Impact of cosmic radiation on absorbed dose rate still needs further investigations.

3. There is no statistically significant difference between indoor radon concentrations in concrete houses and houses built of bricks - the most common construction materials.

4. There might be large differences ( 30 and more times) in the coefficient of increment in absorbed dose rate per unit of increment in indoor radon concentration. It depends on the concentration of indoor radon, floor where premises are situated, geometry of premises.

5. In some cases this coefficient might be negative, however, if indoor radon concentrations are higher than (25-40) $\mathrm{Bq} \cdot \mathrm{m}^{-3}$, it becomes positive, i e absorbed dose rate increases with increase of indoor radon concentration.
6. Using the results of this study it is possible to determine the impact of indoor radon on human exposure, including that coming from radon released from construction materials.

\section{References}

1. Sources and Effects of Ionizing Radiation, United Nations Scientific Committee on the Effects of Atomic Radiation, UNSCEAR 2000. Report to the General Assembly, Vol I, United Nations, New York, 2000, p 87-122.

2. Lebedyte, M.; Butkus, D.; Morkūnas, G. Estimation of external equivalent gamma dose rate caused by gamma radionuclides in soil. Environmental and Chemical Physics, Vol 21, 1999, p 78-82.

3. Lebedyte, M.; Butkus, D. Equivalent dose rate in the ground-level air caused by the ${ }^{222} \mathrm{Rn}$ proseny gamma radiation. Environmental engineering (Aplinkos inžinerija), Vol IX, No 3, 2001, p 153-157.

4. Heath, C. W.; Bond, P. D.; Hoel, D. G.; Meinhold, C. B. Residential radon exposure and lung cancer risk: commentary on Cohen's county-based study. Health Physics, 87(6), 2004, p 675-655.

5. Lee, E. M.; Menezes, G.; Finch, E. C. Natural radioactivity in building materials in the Republic of Ireland. Health Physics, 86(4), 2004, p 378-383.

6. Langroo, M. K.; Wise, K. N.; Duggleby, J. C.; Kotler, L. H. A national survey of ${ }^{222} \mathrm{Rn}$ and $\gamma$ radiation levels in Australian homes. Health Physics, 61(6), 1991, p 753-761.

7. Gasiūnas, K.; Mastauskas, A.; Morkūnas, G. Radon in soil air and indoors in Lithuania. Civil Engineering (Statyba), Vol IV, No 4, 1998, p 316-321 (in Lithuanian).

8. Stoulos, S.; Manolopoulou, M.; Papastefanou, C. Assessment of natural radiation exposure and radon exhalation from building materials in Greece. Journal of Environmental Radioactivity, 69, 2003, p 225-240.

9. Bossew, P. The radon emanation power of building materials, soils and roks. Applied Radiation and Isotopes, 59, 2003, p 389-392.

10. Clavensjo, B.; Akerblom, G.; Morkūnas, G. Indoor radon and measures of reducing its concentration (Radono sąlygotos radono efektinès dozès individualiuosiuose namuose ivertinimas). Vilnius, 1999. 128 p. (in Lithuanian).

11. Morkūnas, G. Assessment of effective dose caused by radon in private houses. Doctoral theses. Vilnius, 2000.

12. Howarth, C. B.; Miles, J. C. H. Results of the 2002 NRPB intercomparison of passive radon detectors. National Radiological Protection Board, NRPB - W44, 2003. 59 p.

13. Leung, J. K. C.; Tso, M. Y. W.; Ho, C. W. Behavior of ${ }^{222} \mathrm{Rn}$ and its progeny in high-rise building. Health Physics, 75(3), 1998, p 303-312.

14. Risica, S.; Nuccetelli, C. Building materials as a source of population exposure to ionizing radiation. Physica Medica, VXVII, No 1, 2001, p 3-8. 


\section{RADONO SKILIMO PRODUKTŲ GAMA SPINDULIUOTĖS ITAKA SUGERTOSIOS DOZĖS GALIAI PATALPOSE}

\section{Pilkytè, D. Butkus}

\section{$\mathrm{S}$ a n t r a u k a}

Buvo atlikti sugertosios dozès galios ir radono tūrinių aktyvumų matavimai daugiaaukščiuose namuose. Pagrindinis radono šaltinis tokiuose pastatuose yra statybinès medžiagos. Nustatyta, kad sugertosios dozès galia ore priklauso nuo radono tūrinio aktyvumo patalpose. Šis ryšys susijęs su patalpu geometrija ir kitais parametrais, kurie turi itakos radono skilimo produktu pasiskirstymui patalpose. Sugertosios dozės galios pokytis priklauso nuo radono tūrinio aktyvumo, aukšto, kuriame yra patalpos, patalpu geometrijos. Šio darbo rezultatus galima panaudoti iš statybinių medžiagų išsiskyrusio radono spinduliuotès lemiamai dozei ivertinti.

Raktažodžiai: gamtiniai radionuklidai, išorinè apšvita, radonas patalpose, sugertosios dozès galia, statybinės medžiagos.

Laima PILKYTE். Doctoral student, Dept of Environmental Protection, Vilnius Gediminas Technical University (VGTU), Saulètekio al. 11, LT-10223 Vilnius-40, Lithuania. Engineer radiologist, Dept of Programs and Expertise, Radiation Protection Centre, Kalvariju g. 153, LT-08221 Vilnius-42, Lithuania. E-mail: 1.pilkyte@rsc.lt

First degree in Physics, Faculty of Physics, Vilnius University, 1985. Publications: author (with co-authors) of 10 papers in Lithuanian and foreign journals. Research interests: natural radioactivity in environment, assessment of internal and external exposure dose to ionizing radiation to general public, gamma spectrometry of building materials and environmental samples, indoor radon.

Donatas BUTKUS. Dr Habil, Prof, Dept of Environmental Protection, Vilnius Gediminas Technical University (VGTU), Saulètekio al. 11, LT-10223 Vilnius-40, Lithuania. E-mail: aak@ap.vtu.lt

Doctor Habil of Science (environmental engineering), VGTU, 1999. Membership: Member of International Academy of Ecology and Life Protection. Publications: author of more than 100 research papers, co-author of the monograph "Geophysical problems of atmospheric krypton-85" (in Russian and English). Research interests: accumulation of radioactive noble gases, their interaction with environmental bodies, self-cleaning of the atmosphere, influence of ionizing radiation of radioactive noble gases on geophysical processes; investigation of the consequences of the Chernobyl accident in Lithuania. 